\title{
Rosalia: an experimental research site to study hydrological processes in a forest catchment
}

\author{
Josef Fürst $^{1}$, Hans Peter Nachtnebel ${ }^{1}$, Josef Gasch ${ }^{2}$, Reinhard Nolz ${ }^{3}$, Michael Paul Stockinger ${ }^{3}$, \\ Christine Stumpp ${ }^{3}$, and Karsten Schulz ${ }^{1}$ \\ ${ }^{1}$ Institute for Hydrology and Water Management (HyWa), University of Natural Resources \\ and Life Sciences Vienna (BOKU), Vienna, Austria \\ ${ }^{2}$ Forest Demonstration Centre, University of Natural Resources \\ and Life Sciences Vienna (BOKU), Vienna, Austria \\ ${ }^{3}$ Institute for Soil Physics and Rural Water Management (SoPhy), University of Natural Resources \\ and Life Sciences Vienna (BOKU), Vienna, Austria \\ Correspondence: Josef Fürst (josef.fuerst@boku.ac.at)
}

Received: 27 August 2020 - Discussion started: 26 November 2020

Revised: 29 June 2021 - Accepted: 14 July 2021 - Published: 19 August 2021

\begin{abstract}
Experimental watersheds have a long tradition as research sites in hydrology and have been used since the late nineteenth and early twentieth centuries. The University of Natural Resources and Life Sciences Vienna (BOKU) recently extended its experimental research forest site "Rosalia" with an area of 950 ha towards the creation of a full ecological-hydrological experimental watershed. The overall objective is to implement a multi-scale, multi-disciplinary observation system that facilitates the study of water, energy and solute transport processes in the soil-plant-atmosphere continuum. This article describes the characteristics of the site and the monitoring network and its instrumentation that has been installed since 2015, as well as the datasets. The network includes four discharge gauging stations and seven rain gauges along with observations of air and water temperature, relative humidity, and electrical conductivity. In four profiles, soil water content and temperature are recorded at different depths. In addition, since 2018, nitrate, TOC and turbidity have been monitored at one gauging station. In 2019, a programme to collect isotopic data in precipitation and discharge was initiated. All data collected since 2015, including, in total, 56 high-resolution time series (with 10 min sampling intervals), are provided to the scientific community on a publicly accessible repository. The datasets are available at https://doi.org/10.5281/zenodo.3997140 (Fürst et al., 2020).
\end{abstract}

\section{Introduction}

Environmentally oriented water management depends on understanding hydrological processes and their dominant controls at different spatial and temporal scales. To investigate hydrological processes and their complex interactions with the environment, long-term measurements from multidisciplinary hydrological observatories are required (Schumann et al., 2010; Blöschl et al., 2016). As the earliest hydrological observatories, experimental watersheds have been used as far back as the late nineteenth and early twentieth centuries (USGS Reynolds Creek; Seyfried et al., 2018).
Given these long-term datasets, changes in the hydrological cycle, such as those resulting from climate warming, can be investigated in these watersheds (Bogena et al., 2018).

In recent decades, there has been growing recognition that hydrology (and its related disciplines) cannot be treated in isolation. Rather, hydrological processes driven by meteorological conditions are also strongly controlled by complex feedback mechanisms with biotic and abiotic systems (Porporato and Rodriguez-Iturbe, 2002). Therefore, hydrological experimental watersheds have gradually transitioned into multi-disciplinary experimental watersheds. A prominent example for this is the "Critical Zone Observatories" research 
project, which was initiated in 2007 by the US National Science Foundation (Anderson et al., 2018) and has been succeeded by the Critical Zone Collaborative Network (CZN) in 2021.

Understanding processes based on research conducted at individual catchments is limited to the physio-geographic conditions at the particular location. In an effort to understand hydrological processes based on a wider spectrum of boundary conditions, networks of multi-disciplinary hydrological observatories have been established in recent decades. Examples of such networks are the German "TERrestrial ENvironmental Observatory network" (TERENO) (Zacharias et al., 2011), the "International Network for Alpine Research Catchment Hydrology" (Bernhardt et al., 2015), the "US National Science Foundation's National Ecological Observatory Network" (NEON) (Kampe et al., 2010), and the "Euro-Mediterranean Network of Experimental and Representative Basins" (ERB) as part of UNESCO FRIEND (Flow Regimes from International Experimental and Network Data) (Holzmann, 2018).

A prominent example of an observatory network is the "Long-Term Ecosystem Research" (LTER) initiative, which aims to better understand the structure and functioning of complex ecosystems and their long-term response to environmental, societal and economic pressures at different spatial scales (LTER Network Office, 2020). The LTER was initiated in 1980 with six US catchments and has since expanded to other continents, comprising different ecosystem types, climates and pressures. The LTER was further developed into the "Long Term Socio-economic and Ecosystem Research" (LTSER) platform to emphasise the importance of the human dimension and to explicitly consider the socio-economic system in multi-disciplinary ecosystem research (Haberl et al., 2006). The European LTER is the "European Long-Term Ecosystem, Critical Zone and Socio-Ecological Systems Research Infrastructure" (eLTER RI), which was established in 2003 by the European Commission as part of the "European Strategy Forum on Research Infrastructures" (ESFRI) (ESFRI, 2020).

These networks of observatories make it possible to address some open research questions in hydrology that were recently formulated (Blöschl et al., 2019). The most challenging questions regarding catchment hydrology relate to the effect of small-scale variability in the upscaling of model parameters and processes (e.g., hydraulic conductivity and porosity of soils, soil water movement), the transfer of model parameters to other (especially ungauged) catchments, and the derivation of flow paths and residence times of water and solutes in the subsurface at different scales. Overcoming these challenges requires the existing networks of observatories to be complemented in their instrumentation and observational capacities, harmonising temporal and spatial frequencies and continuously monitoring natural tracers such as ions, metals and stable isotope ratios such as ${ }^{2} \mathrm{H} /{ }^{1} \mathrm{H}$, ${ }^{18} \mathrm{O} /{ }^{16} \mathrm{O}$ and ${ }^{15} \mathrm{~N} /{ }^{14} \mathrm{~N}$ in precipitation, discharge and the subsurface. The Plynlimon research catchment in the UK (Neal et al., 2011; Cosby and Emmett, 2020) and the Krycklan catchment study in Sweden (Laudon et al., 2013) are good examples of such research catchments, with long term tracer and hydro-geochemical data available.

The University of Natural Resources and Life Sciences in Vienna (BOKU) has a long tradition and extensive experience in operating multi-disciplinary experimental sites. BOKU has been using these sites for research purposes to monitor environmental changes and climate change impacts, to develop new monitoring techniques, and to train students in applied research. One of BOKU's sites is the experimental research forest "Rosalia", with an area of 950 ha that was established in 1875 to facilitate research and education, mainly in forestry disciplines (Fig. 1). Several forest dieback studies were conducted in the 1980s. In 2013, a 222 ha watershed within the Rosalia forest site was established as an ecohydrological experimental watershed, and this Rosalia watershed became part of the Austrian LTER-CWN (Research Infrastructure for Carbon, Water and Nitrogen) initiative.

The overall objective is to implement a multi-scale, multidisciplinary observatory that facilitates the study of water, energy and solute transport processes in the soil-plantatmosphere continuum. Research emphasis is put on deriving effective parameters for scales on which models simulate flow and transport processes (e.g. hillslope, catchment) by upscaling point measurements. A distinctive feature of the current monitoring setup is the continuous measurement of tracers in precipitation and discharge of selected creeks within the catchment, which allows us to derive travel time distributions for sub-catchments and investigate flow pathways in detail. Because BOKU has the right of access for educational and research purposes, large-scale controlled experiments can be undertaken. For example, rain-out shelters were used in parts of the forest by Netherer et al. (2015) to investigate drought impacts on bark beetle attacks on Norway spruce, while Schwen et al. (2015) and Leitner et al. (2017) used rain-out shelters to investigate soil water repellency and short-term organic nitrogen fluxes under a changing climate. Besides such local experiments, the monitoring network established in 2015 enables researchers to investigate the impacts on the large-scale forest ecosystem and its services by providing the necessary baseline data. Investigating the transition of the forest ecosystem from its actual state into a pristine, unmanaged natural forest is among future research plans.

The objective of this article is to present the monitoring network and the recorded data of the Rosalia watershed and to make them available to the scientific community.

\section{Description of the watershed}

The Rosalia watershed is part of the Rosalia mountains (German: Rosaliengebirge) that belong to the eastern foothills 

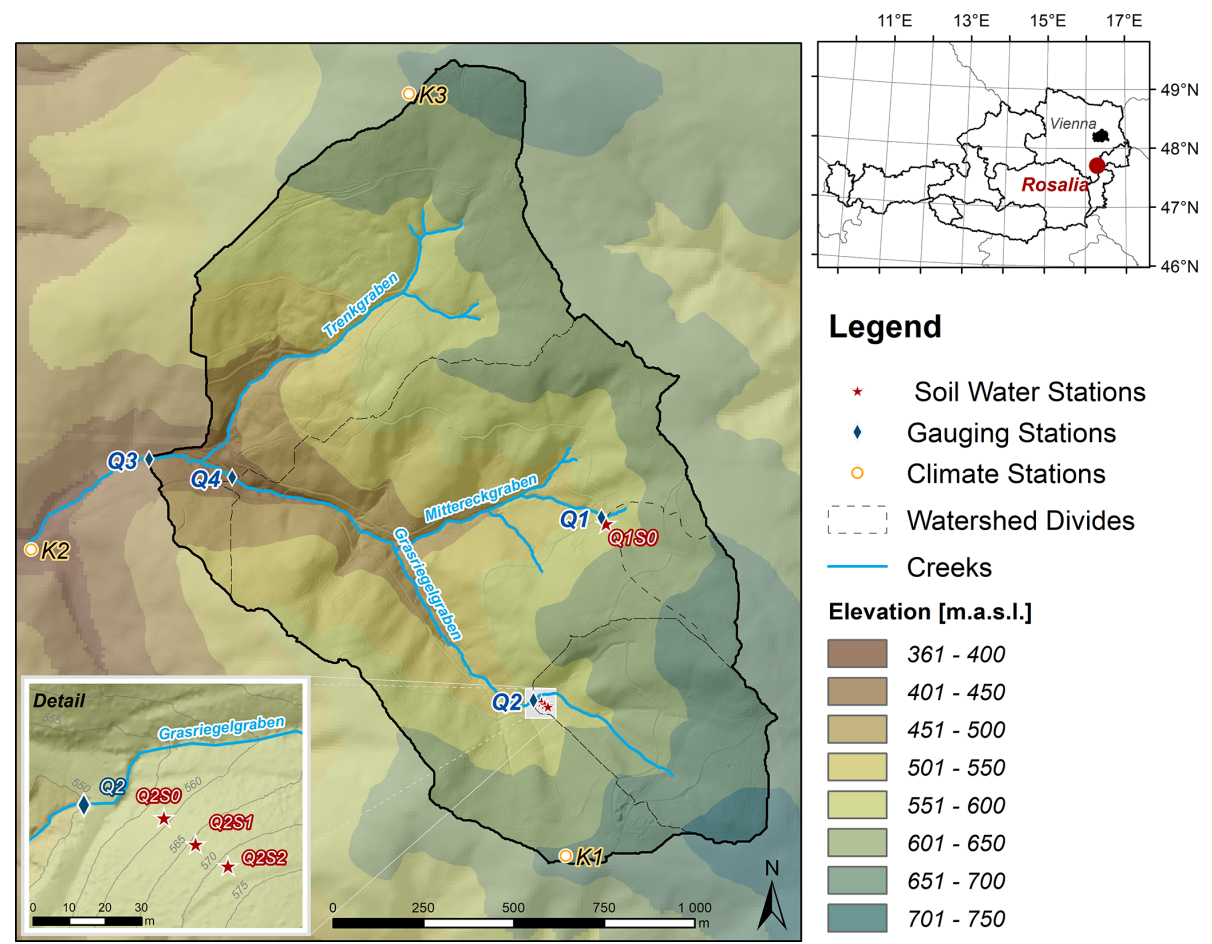

\section{Legend}

* Soil Water Stations

- Gauging Stations

- Climate Stations

Watershed Divides

Creeks

Elevation [m.a.s.I.]

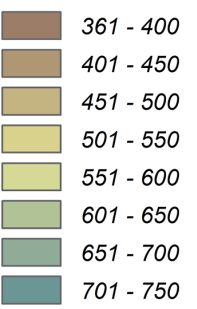

Figure 1. Map of the watersheds and the monitoring network (DEM source: Land Niederösterreich - http://data.noe.gv.at, last access: 29 June 2021).

of the Alps on the state border between Lower Austria and Burgenland in Austria (Fig. 1). Terrain heights range from 385 to $725 \mathrm{~m}$ a.s.l., and the watershed is characterised by steep slopes $(96 \%$ of the area is steeper than $10 \%$, and $55 \%$ is steeper than 30\%). From 1990 to 2017, annual precipitation was between 560 and $1100 \mathrm{~mm}$ (average $790 \mathrm{~mm}$, standard deviation $128 \mathrm{~mm}$ ), and the mean annual air temperature was between 5.5 and $10^{\circ} \mathrm{C}$ (average $8.2^{\circ} \mathrm{C}$, standard deviation $1.2^{\circ} \mathrm{C}$ ) (data: https://deims.org/ dataset/839e7779-f6ee-4b81-b4d8-924177b9c562, last access: 29 June 2021). Precipitation is not equally distributed throughout the year. Frequently in summer, heavy thunderstorms occur, causing floods that destroy forest roads, road culverts and other infrastructure (Fig. 2).

Crystalline rocks dominate in the Rosalia mountains, but coarse-grained gneiss, sericitic schist, phyllite and dolomite are also encountered. However, only coarse-grained gneiss with occasionally embedded dark or white mica schist is found in the actual catchment area of the hydrological research site.

The soils are predominantly cambisols that can be classified into four categories (Fig. 3). The source materials for the recent soil formation are often remnants of tertiary soils that were modified by frost action and landslides during the ice age. The cambisols on steep slopes (slope $>40 \%$, category 1 in Fig. 3) cover $5 \%$ of the area. They are podzolic cambisols with more than $40 \%$ coarse grain. These sites

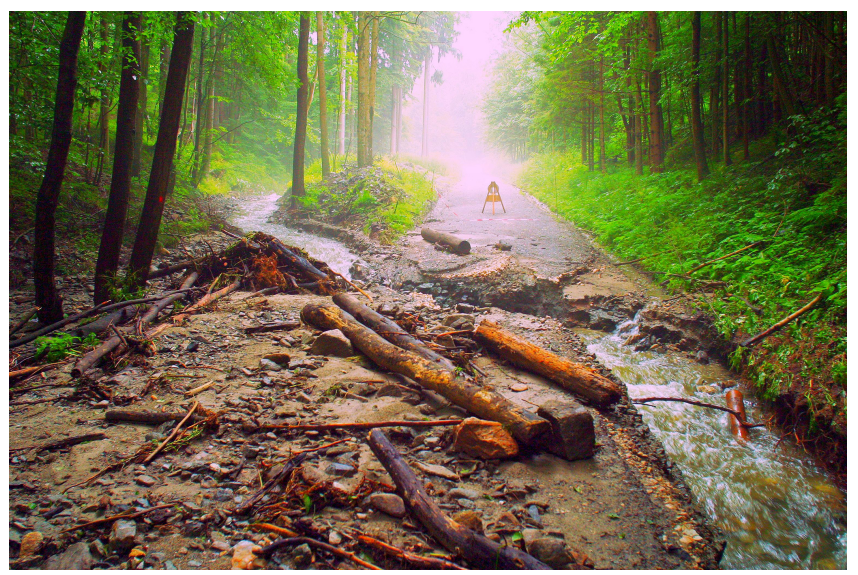

Figure 2. Destructions of forest roads due to a storm on 29 June 2009 (Photo: Josef Gasch).

are characterised by poor water holding capacity and loss of organic material due to gravitational transport and wind erosion. The characteristic species for these sites are beech with white woodrush (Luzula albida) associated with pine (Pinus sylvestris) and European larch (Larix decidua) above $500 \mathrm{~m}$ a.s.l., while below $500 \mathrm{~m}$ a.s.l. they are associated with oak (Quercus petraea). Cambisols on plains and moderate slopes (category 2 in Fig. 3, $68 \%$ of the area) contain 30\%$50 \%$ coarse grain and have a medium water holding capac- 


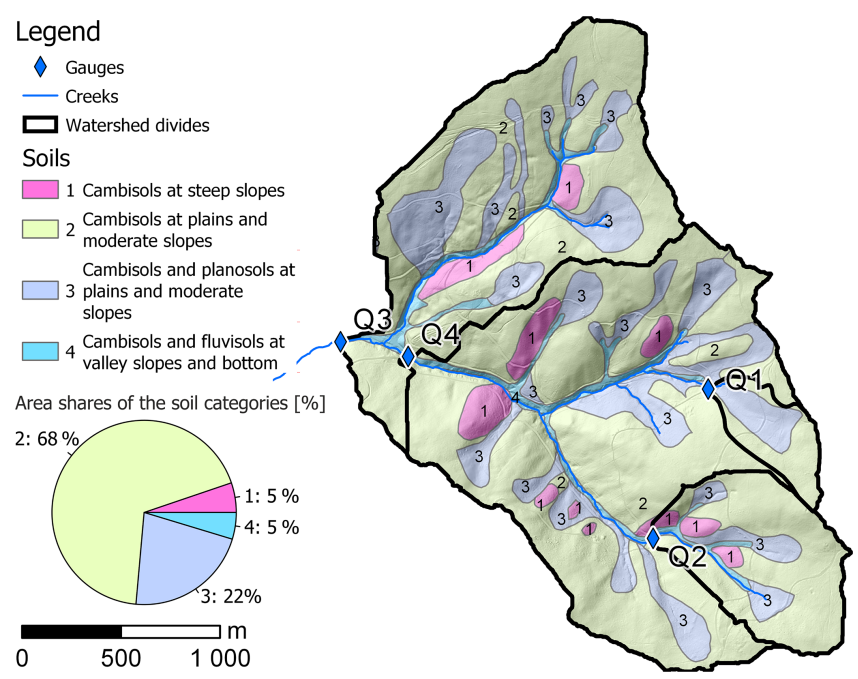

Figure 3. Soil map with the four main soil categories, watershed divides and discharge gauges.

ity. The characteristic species is beech with woodruff ( $\mathrm{Gal}$ ium odoratum). At higher elevations and cool north slopes, beech, spruce and fir (abieti-fagetum) are found. Cambisol and planosol on plains and moderate slopes (category 3 in Fig. 3, 22\% of the area) are characterised by periodic water stagnation. They are typically on concave land forms and have good water capacity and nutrient sustenance. There is a risk of wind throw due to possible root dieback in long wet periods. Forest associations are the same as for category 2. Cambisol and fluvisol on valley slopes and bottoms (category $4,5 \%$ of the area) are characterised by varying contents of coarse material and profile thickness but always have good nutrient and water supply. Where valleys form a flat bottom, fluvisols are the basis for plant growth. The dominant tree species on the slopes are ash and sycamore (acerifraxinetum), while ash and black alder (pruno-fraxinetum) dominate the valley floors.

Forest management is undertaken by the Austrian Federal Forests (OeBf; Österreichische Bundesforste) owned by the Republic of Austria. BOKU has the right of access for educational and research purposes. OeBf manages the forest sustainably, balancing the protection of the environment, the needs of society and economic success. The management of the forest is characterised by long production cycles of 100 to 140 years. The main species of the forest are the broadleaved beech (Fagus sylvatica) and the coniferous Norway spruce (Picea abies). The forest is at different development stages ranging from clear cut areas to mature forest stands. Natural regeneration is preferred to planting, and fertilisation is almost never done. Timber harvesting is usually done with harvesters and forwarders, and cable cranes are used on steep slopes. Management and timber transport are supported by a dense network of forest roads $(50 \mathrm{~m}$ per hectare), suitable for heavy timber trucks. Main threats to the forest are snow break, wind throw and bark beetles, the latter affecting mainly coniferous tree species.

The main advantages of Rosalia as a research site are as follows:

1. The watershed is part of the larger 950 ha forest site used by BOKU, and therefore a large amount of watershed information already exists, including soil maps, high-resolution DEMs (digital elevation models), maps on forest growth and productivity, detailed topographic maps, etc.

2. There is a well-established cooperation between BOKU and the owners of the forest, the Austrian Federal Forests, which facilitates even large-scale experiments with durations of several years.

3. Rosalia can be reached from Vienna within less than an hour, making maintenance cost-effective.

4. BOKU has an educational centre right at the border of the watershed with seminar rooms, basic laboratory facilities and accommodation for up to 40 persons. Resident staff at the educational centre can assist in urgent situations, such as a storm or power failure.

\section{Network of measurement sites}

A network of stations (Fig. 1, Tables 1 and 2) has been set up to collect hydro-meteorological data: at four gauging stations, river discharge, water and air temperature, relative humidity, and electrical conductivity of water are monitored. The locations were selected to cover nested sub-watersheds of 9, 27, 146 and $222 \mathrm{ha}$. At one of these sites (Q4, 146 ha), water quality $\left(\mathrm{NO}_{3}-\mathrm{N}, \mathrm{TOC}\right.$, turbidity) is monitored with a $\mathrm{S}:$ :can multi::lyser ${ }^{\mathrm{TM}}$ spectrometer probe. Here, also stream water samples are taken for analysing stable isotopes of oxygen $\left(\delta^{18} \mathrm{O}\right)$ and hydrogen $\left(\delta^{2} \mathrm{H}\right)$. Precipitation is measured by seven rain gauges at different altitudes. At two of these locations, $\mathrm{K} 1$ and Q4, precipitation is additionally collected for the analysis of $\delta^{18} \mathrm{O}$ and $\delta^{2} \mathrm{H}$. At four locations, soil profiles were equipped with sensors measuring soil water content (SWC), electrical conductivity of soil water, and soil temperature at four and three depths, respectively.

\subsection{Data acquisition}

Although the observed variables have different temporal characteristics, it was decided to record all in situ measurements (except stable water isotope data) at synchronous 10 min intervals to simplify data storage and organisation. For this purpose, a UHF radio telemetry network (ADCON telemetry by OTT Hydromet $\mathrm{GmbH}$ ) was implemented, enabling data acquisition, storage and management by a webaccessible database management system (DBMS). At each monitoring site, different sensors are connected to a remote 
Table 1. List of sites, sensors and observed variables.

\begin{tabular}{|c|c|c|}
\hline Site & Sensors & Observed variables \\
\hline \multirow{5}{*}{$\begin{array}{l}\text { Q1 } \\
\text { Mittereckgraben } \\
559.87 \text { m a.s.1 } \\
\text { Watershed } 9 \text { ha }\end{array}$} & Conductivity and temperature sensor Ponsel C4E & Electrical conductivity and water temperature \\
\hline & Rain gauge RG1 (Adcon tipping bucket) & 10 min rain depth \\
\hline & Air temperature and humidity sensor TR1 (Adcon) & $\begin{array}{l}\text { Air temperature } \\
\text { Relative humidity }\end{array}$ \\
\hline & 1-ft H-flume with two ultrasonic distance sensors (Baumer) & $\begin{array}{l}\text { Water level in H-flume } \\
\text { Discharge }\end{array}$ \\
\hline & Tipping bucket, $1 \mathrm{~L}$ per tip (for discharge $<0.02 \mathrm{~L} \mathrm{~s}^{-1}$ ) & Small discharge \\
\hline $\begin{array}{l}\text { Q1S0 } \\
\text { Soil water profile }\end{array}$ & $\begin{array}{l}\text { Four HydraProbe soil sensors (Stevens) at Q1S0 } \\
\text { Sensor depths: } 10,20,40,60 \mathrm{~cm}\end{array}$ & $\begin{array}{l}\text { Soil water content } \\
\text { Soil temperature } \\
\text { Electrical conductivity of soil water }\end{array}$ \\
\hline \multirow{4}{*}{$\begin{array}{l}\text { Q2 } \\
\text { Grasriegelgraben } \\
550.06 \text { m a.s.1 } \\
\text { Watershed } 27 \text { ha }\end{array}$} & Conductivity and temperature sensor Ponsel C4E & $\begin{array}{l}\text { Electrical conductivity } \\
\text { Water temperature }\end{array}$ \\
\hline & Rain gauge RG1 (tipping bucket) & 10 min rain depth \\
\hline & Air temperature and humidity sensor TR1 & $\begin{array}{l}\text { Air temperature } \\
\text { Relative humidity }\end{array}$ \\
\hline & 1-ft $\mathrm{H}$-flume with two ultrasonic distance sensors & $\begin{array}{l}\text { Water level in } \mathrm{H} \text {-flume } \\
\text { Discharge }\end{array}$ \\
\hline $\begin{array}{l}\text { Q2S0 } \\
\text { Soil water profile }\end{array}$ & $\begin{array}{l}\text { Four HydraProbe soil sensors at Q2S0 } \\
\text { Sensor depths: } 10,20,40,60 \mathrm{~cm}\end{array}$ & For parameters, see above \\
\hline $\begin{array}{l}\text { Q2S1 } \\
\text { Q2S2 } \\
\text { Soil water profiles }\end{array}$ & $\begin{array}{l}\text { Three HydraProbe soil sensors at Q2S1 and Q2S2 } \\
\text { Sensor depths: 10, 20, } 40 \mathrm{~cm}\end{array}$ & For parameters, see above \\
\hline \multirow{3}{*}{$\begin{array}{l}\text { Q3 } \\
\text { Weir Grasriegelgraben } \\
410 \mathrm{~m} \text { a.s.1 } \\
\text { Watershed } 222 \text { ha }\end{array}$} & Depth sensor Keller PR46X & $\begin{array}{l}\text { Water level at weir } \\
\text { Discharge }\end{array}$ \\
\hline & Rain gauge RG1 (tipping bucket) & 10 min rain depth \\
\hline & Air temperature and humidity sensor TR1 & $\begin{array}{l}\text { Air temperature } \\
\text { Relative humidity }\end{array}$ \\
\hline \multirow{7}{*}{$\begin{array}{l}\text { Q4 } \\
\text { Grasriegelgraben } \\
415 \mathrm{~m} \text { a.s.1 } \\
\text { Watershed } 146 \text { ha }\end{array}$} & 2-ft H-flume with two ultrasonic distance sensors (Baumer) & $\begin{array}{l}\text { Water level in } \mathrm{H} \text {-flume } \\
\text { Discharge }\end{array}$ \\
\hline & Rain gauge RG1 (tipping bucket) & 10 min rain depth \\
\hline & Air temperature and humidity sensor TR 1 & $\begin{array}{l}\text { Air temperature } \\
\text { Relative humidity }\end{array}$ \\
\hline & S::can conductivity and temperature sensor condu:lyser & $\begin{array}{l}\text { Electrical conductivity } \\
\text { Water temperature }\end{array}$ \\
\hline & S::can multi::lyser spectrometer probe & $\mathrm{TOC}, \mathrm{NO}_{3}-\mathrm{N}$, turbidity \\
\hline & Palmex rain sampler & Precipitation isotopes $\left(\delta^{18} \mathrm{O}, \delta^{2} \mathrm{H}\right)$ \\
\hline & Teledyne ISCO full-size portable sampler 6712 & River water isotopes $\left(\delta^{18} \mathrm{O}, \delta^{2} \mathrm{H}\right)$ \\
\hline \multirow{3}{*}{$\begin{array}{l}\text { K1 } \\
\text { Heuberg } \\
640 \text { m a.s.1 }\end{array}$} & OTT Pluvio $^{2} \mathrm{~L}$ - weighing rain gauge & 10 min rain depth \\
\hline & Air temperature and humidity sensor TR1 & $\begin{array}{l}\text { Air temperature } \\
\text { Relative humidity }\end{array}$ \\
\hline & Palmex - rain sampler & Precipitation isotopes $\left(\delta^{18} \mathrm{O}, \delta^{2} \mathrm{H}\right)$ \\
\hline \multirow{2}{*}{$\begin{array}{l}\text { K2 } \\
\text { Mehlbeerleiten } \\
385 \text { m a.s.l }\end{array}$} & OTT Pluvio $^{2} \mathrm{~L}$ - weighing rain gauge & 10 min rain depth \\
\hline & Air temperature and humidity sensor TR1 & $\begin{array}{l}\text { Air temperature } \\
\text { Relative humidity }\end{array}$ \\
\hline $\begin{array}{l}\text { K3 } \\
\text { Krieriegel } \\
655 \text { m a.s.1 }\end{array}$ & OTT Pluvio $^{2} \mathrm{~L}$ - weighing rain gauge & 10 min rain depth \\
\hline
\end{tabular}


Table 2. Specifications of sensors. Last access date of all URLs: 29 June 2021.

\begin{tabular}{|c|c|c|c|c|}
\hline Sensor & Variable & Range & Resolution & Accuracy \\
\hline $\begin{array}{l}\text { Adcon RG1 tipping bucket rain } \\
\text { gauge } \\
\text { http://www.adcon.at }\end{array}$ & Precipitation $(\mathrm{mm})$ & $0-200 \mathrm{~mm} / \mathrm{h}$ & $0.2 \mathrm{~mm}$ & $\begin{array}{l}<50 \mathrm{~mm} \mathrm{~h}^{-1} \pm 1 \% \\
50-100 \mathrm{~mm} \mathrm{~h}^{-1} \pm 3 \% \\
100- \\
200 \mathrm{~mm} \mathrm{~h}^{-1} \pm 5 \%\end{array}$ \\
\hline $\begin{array}{l}\text { Ott Pluvio }{ }^{2} \text { weighing } \\
\text { rain gauge } \\
\text { https://www.ott.com }\end{array}$ & Precipitation $(\mathrm{mm})$ & $\begin{array}{l}12- \\
1800 \mathrm{~mm} \mathrm{~h}^{-1}\end{array}$ & $0.01 \mathrm{~mm} \mathrm{~min}^{-1}$ & $\pm 0.05 \mathrm{~mm}$ \\
\hline $\begin{array}{l}\text { Adcon TR } 1 \text { air temperature and } \\
\text { humidity } \\
\text { http://www.adcon.at }\end{array}$ & $\begin{array}{l}\text { Air temperature }\left({ }^{\circ} \mathrm{C}\right) \\
\text { Relative humidity }(\% \mathrm{RH})\end{array}$ & $\begin{array}{l}-40 \text { to }+60^{\circ} \mathrm{C} \\
0-100 \% \mathrm{RH}\end{array}$ & $\pm 0.1^{\circ} \mathrm{C}$ & $\begin{array}{l} \pm 0.1^{\circ} \mathrm{C} \\
\pm 1 \% \mathrm{RH} \text { at } 0 \% \mathrm{RH}- \\
90 \% \mathrm{RH} \\
\pm 2 \% \mathrm{RH} \text { at } 90 \% \mathrm{RH}- \\
100 \% \mathrm{RH}\end{array}$ \\
\hline $\begin{array}{l}\text { UGT - 1-ft H-flume } \\
\text { https://www.ugt-online.de }\end{array}$ & Discharge $\left(\mathrm{L} \mathrm{s}^{-1}\right)$ & $0.02-55 \mathrm{~L} \mathrm{~s}^{-1}$ & & $2 \%-5 \%$ \\
\hline $\begin{array}{l}\text { UGT - 2-ft H-flume } \\
\text { https://www.ugt-online.de }\end{array}$ & Discharge $\left(\mathrm{Ls}^{-1}\right)$ & $0.04-315 \mathrm{Ls}^{-1}$ & & $2 \%-5 \%$ \\
\hline $\begin{array}{l}\text { Keller PR-46X water level } \\
\text { https://keller-druck.com }\end{array}$ & Water level (m) & $0-1 \mathrm{~m}$ & $<1 \mathrm{~mm}$ & $\pm 0.55 \mathrm{~mm}$ \\
\hline $\begin{array}{l}\text { Ponsel C4E water } \\
\text { temperature and electrical } \\
\text { conductivity } \\
\text { https://en.aqualabo.fr }\end{array}$ & $\begin{array}{l}\text { Water temperature }\left({ }^{\circ} \mathrm{C}\right) \\
\text { Electrical conductivity } \\
\left(\mu \mathrm{S} \mathrm{cm}^{-1}\right)\end{array}$ & $\begin{array}{l}0-50{ }^{\circ} \mathrm{C} \\
0-2000 \mu \mathrm{S} \mathrm{cm}^{-1}\end{array}$ & $\begin{array}{l}0.01^{\circ} \mathrm{C} \\
<0.1 \mu \mathrm{S} \mathrm{cm}^{-1}\end{array}$ & $\begin{array}{l} \pm 0.5^{\circ} \mathrm{C} \\
\pm 1 \% \text { of the full range }\end{array}$ \\
\hline $\begin{array}{l}\text { s::can condu::lyser }{ }^{\mathrm{TM}} \text { water } \\
\text { temperature and electrical } \\
\text { conductivity } \\
\text { https://www.s-can.at }\end{array}$ & $\begin{array}{l}\text { Water temperature }\left({ }^{\circ} \mathrm{C}\right) \\
\text { Electrical conductivity } \\
\left(\mu \mathrm{S} \mathrm{cm}^{-1}\right)\end{array}$ & $\begin{array}{l}-20-130{ }^{\circ} \mathrm{C} \\
0- \\
500000 \mu \mathrm{S} \mathrm{cm}^{-1}\end{array}$ & $\begin{array}{l}<0.1^{\circ} \mathrm{C} \\
1 \mu \mathrm{S} \mathrm{cm}^{-1}\end{array}$ & $\begin{array}{l}\text { Not specified } \\
\pm 1 \% \text { of value }\end{array}$ \\
\hline $\begin{array}{l}\text { Stevens HydraProbe II } \\
\text { https://www.stevenswater.com }\end{array}$ & $\begin{array}{l}\text { Soil water content }\left(\mathrm{cm}^{3} \mathrm{~cm}^{-3}\right) \\
\text { Electrical conductivity } \\
\left(\mathrm{dS} \mathrm{m}{ }^{-1}\right) \\
\text { Soil temperature }\left({ }^{\circ} \mathrm{C}\right)\end{array}$ & $\begin{array}{l}\text { Dry to saturated } \\
0-20 \mathrm{dS} \mathrm{m}^{-1} \\
-10 \text { to }+65^{\circ} \mathrm{C}\end{array}$ & & $\begin{array}{l} \pm 3 \% \\
\pm 2 \% \text { or } \pm 0.2 \mathrm{dS} \mathrm{m}^{-1} \\
\pm 0.6^{\circ} \mathrm{C}\end{array}$ \\
\hline
\end{tabular}

telemetry unit (RTU). Within the network, several RTUs store and transmit data to a base station (located at the education centre building) and receive control commands from the base station. Apart from physically connecting the sensors to the RTU and providing a power supply (solar or external), all setup, parameterisation, etc. are done remotely via a web interface to the base station.

The DBMS addVANTAGE Pro, which is connected to the base station via an internet link, is the main interface for administrators, regular users and the public. It is ADCON's universal data visualisation, processing and distribution platform. It is fully web-based, runs on a reliable PostgreSQL database engine and is fully scalable from a single user version for five RTUs to servers with thousands of clients and thousands of RTUs. The addVANTAGE Pro interface was configured to provide intuitive diagnostic displays of the measured hydro-meteorological variables, as well as of hardware state and broadcasting parameters. Pre-defined conditions, such as power failure or exceedance of certain thresholds in the data, can trigger e-mail alerts to site administrators to enable timely remediation of issues, avoiding or reducing gaps in the records.

Stable water isotope data are not automatically uploaded to the DBMS, but samples are collected on-site and picked up manually by university staff for analysis in the laboratory. Precipitation samples are collected bi-weekly with totalisators with plans to refine the sampling interval to daily, while streamflow samples are collected as daily grab samples using an autosampler. 


\subsection{Description of sites}

\subsubsection{Discharge gauges}

The sites for discharge measurements were selected to collect data for nested sub-catchments of different sizes. It was possible to find locations just at culverts of forest access roads, which has several advantages: (i) the sites are accessible by car, which is important for cost-effective maintenance; (ii) they have a defined sub-catchment outlet; and (iii) the $\mathrm{H}$ flume devices could be mounted directly on culverts, which meant that the road embankments could be used to fully capture even larger flows.

$\mathrm{H}$-flume devices were selected to measure discharge as they cover a wide range of flow rates and most sediments are flushed through due to their horizontal bottom (Morgenschweis, 2010). For sites Q1 and Q2 with a watershed size of 9 and 27 ha, respectively, the 1-foot $\mathrm{H}$-flumes can measure discharge from 0.02 up to $55 \mathrm{~L} \mathrm{~s}^{-1}$, in which the upper limit corresponds to an approximately 5 -year flood discharge (at the 27 ha site). Site Q4, with a watershed of 146 ha, is equipped with a 2-foot $\mathrm{H}$ flume (Fig. 4). Water level at the $\mathrm{H}$-flumes is measured by pairs of ultrasonic distance sensors. One of these sensors measures the depth to the water level, and the second measures a fixed reference distance. With the ratio of known reference distance to measured distance, the depth to water level is corrected for the dependence of the speed of sound on air temperature and relative humidity. Although H-flumes are comparatively insensitive to sediment accumulation, we developed a compressed-air flushing system to keep the outflow section and the water level reference point free of sediments and debris. Site Q3 (222 ha) was already constructed in the 1980s using a Thomson weir (Thomson, 1859). The water level at Q3 is measured by a capacitive pressure transmitter.

Sites Q1, Q2 and Q4 are additionally equipped with sensors for electrical conductivity, water temperature, air temperature and relative humidity. At sites Q1 and Q2, Ponsel C4E sensors (four electrodes) were installed to measure water temperature and conductivity as they have an SDI-12 interface and low power consumption. They work electronically reliably, but the measured conductivities are sensitive to biofilms on the sensor, and the internal firmware requires more than an hour to achieve a stable reading after turning on or after cleaning. Furthermore, the measured conductivity tends to show an offset compared to manual measurements conducted approximately bi-weekly. Nevertheless, the recorded curves show plausible dynamics, e.g., during storm events. Currently, alternative sensors are being tested to replace the C4E devices. At site Q4, a different type of sensor (s::can condu::lyser ${ }^{\mathrm{TM}}$ ) is used, which, after more than a year of operation, recorded reliable and stable data.

\subsubsection{Rain gauges}

Sites K1, K2 and K3 are equipped with OTT Pluvio ${ }^{2}$ weighing rain gauges. Antifreeze fluid is added during the frost period so that continuous measurements are possible. At the discharge sites Q1 to Q4, tipping bucket rain gauges are installed. They require more maintenance than weighing rain gauges because the funnel is easily blocked by deposition of leaves, pollen, dust or insects, and they are inoperable during frost. Records from November to April must therefore be carefully checked using air temperature records and comparing the data with the records from the weighing rain gauges. Furthermore, it was not possible to place all rain gauges in the forest in such a way that no negative wind influences occur. Particularly, the recommendation that the height of nearby objects, such as trees, should not exceed the distance from the gauge to the objects (WMO, 2008) had to be disregarded for Q1 and Q2. In particular, the rain gauge at Q1 is directly affected by the interception of the trees above.

\subsubsection{Soil water}

Stevens ${ }^{\circledR}$ HydraProbe ${ }^{\circledR}$ soil sensors (Stevens Water Monitoring Systems, Inc., Portland, OR, USA) were installed to simultaneously measure soil moisture, temperature and salinity (Stevens Water Monitoring Systems, 2015). The sensors deliver a standard data packet of six variables, including three variables characterising the dielectric properties of the soil and the resulting values of soil water content, temperature and bulk electrical conductivity. The sensor-internal calculation of soil water content refers to the general calibration function published by Seyfried et al. (2005). In total, four soil profiles were equipped with HydraProbes. In two of the profiles, the sensors were installed at depths of 10, 20, 40 and $60 \mathrm{~cm}$ below the surface (Fig. 5); in the others, the sensors were installed at 10,20 and $40 \mathrm{~cm}$ depth. Soil profile Q1S0 is located approximately $20 \mathrm{~m}$ upslope of gauge Q1. Soil profiles Q2S0, Q2S1 and Q2S2 form a transect up the slope line at 16, 30 and $45 \mathrm{~m}$ distance from Q2. This design supports a transect of soil water parameters measured along the slope line (Fig. 1).

\subsubsection{Water quality}

Since 2018 , the water quality parameters $\mathrm{NO}_{3}-\mathrm{N}$, TOC and turbidity have been monitored with a spectrometer probe, s::can multi::lyser ${ }^{\mathrm{TM}}$, at site Q4. In June 2019, two rain totalisators (Palmex Ltd., Croatia) specifically designed to minimise isotope fractionation were installed to collect precipitation samples for isotope analysis at meteorological station K1 and discharge site Q4. At the same site, a Teledyne ISCO full-size portable autosampler with a capacity of $241 \mathrm{~L}$ bottles (model no: 6712) was installed to collect water samples for the laboratory analysis of $\delta^{18} \mathrm{O}$ and $\delta^{2} \mathrm{H}$. A daily sampling interval with $500 \mathrm{~mL}$ of water per sample was chosen to cover long-term changes in base flow and allow for daily 


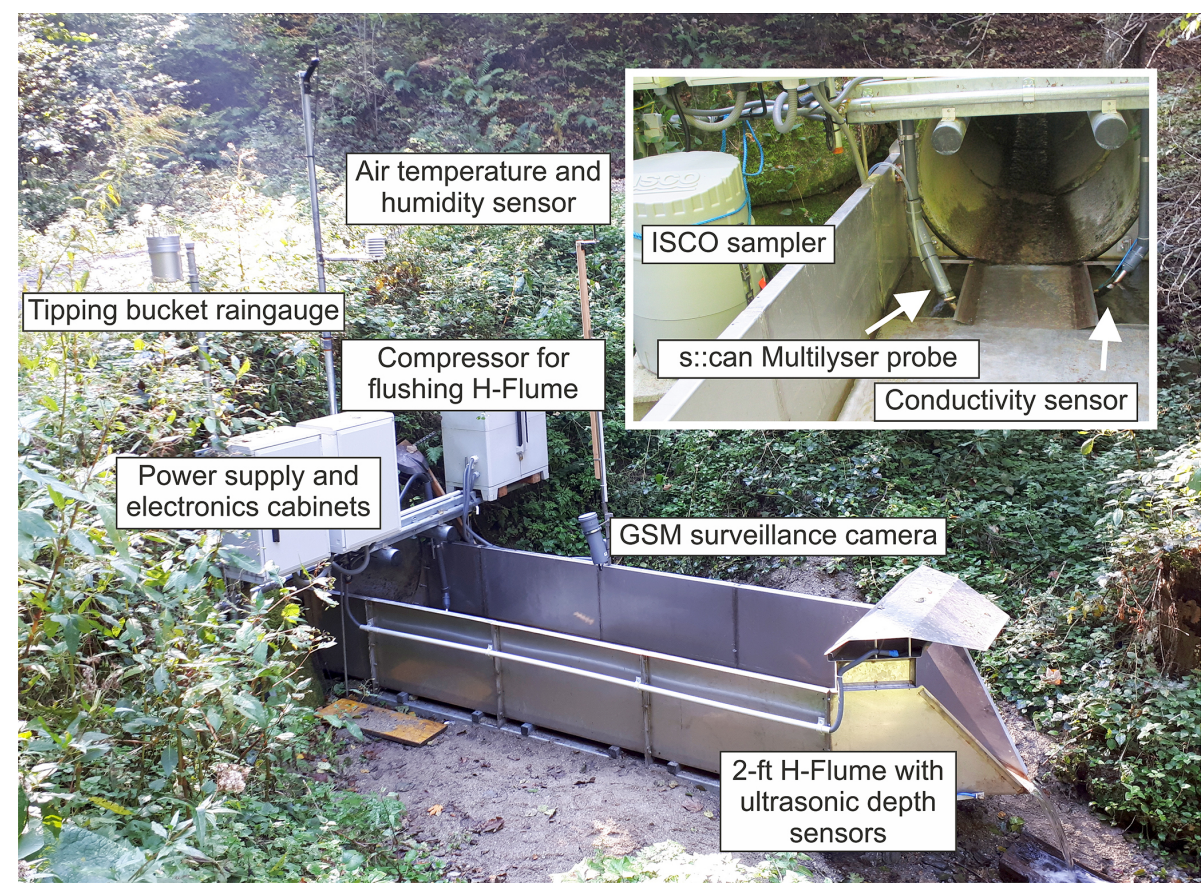

Figure 4. Gauging site Q4 with 2-ft H-flume, spectrometer device and ISCO autosampler.

snapshot information in case of events. The amount of water ensures a statistically sound sample size, while the sampling interval is short enough to enable the investigation of runoff events and is long enough that the autosampler can be left in the field for $24 \mathrm{~d}$ without maintenance. The suction tube leading from the $\mathrm{H}$-flume to the autosampler is occasionally affected by frost. The frozen water inside the tube prevents the autosampler pump from collecting water samples. Since the installation of the system, this has happened only rarely (less than 20d), and we plan on further measures to mitigate freezing issues arising from small amounts of residual water in the tube that the pump cannot fully flush out. A potential evaporation issue arises from the fact that the autosampler is not a cooled field sampler and the sample bottles are open to the sampler's internal atmosphere. Hence, we manually collected streamflow grab samples in closed high density polyethylene (HDPE) bottles each time the field site was visited and measured their isotope ratio within a few days. These values were then compared to those of the sampling bottle which was standing the longest in the field. Preliminary results indicated no major evaporation enrichment problem with a mean difference in $\delta^{18} \mathrm{O}$ of $0.11 \%$ or more than a year of data (measurement uncertainty of $0.1 \%$ ). Nonetheless, occasionally larger deviations up to $0.4 \%$ o were observed. To minimise possible evaporation effects we adapted the sampling bottles according to a recent publication (von Freyberg et al., 2020) by placing a $100 \mathrm{~mm}$ syringe (without the needle) into the opening of the sampling bottle which effectively reduced the area open to atmosphere to a $2 \mathrm{~mm}$ diameter opening (the tip of the syringe body).
Close to the autosampler, open precipitation samples are collected approximately bi-weekly with a totalisator station (Palmex Ltd., Croatia) which is suitable for isotope sampling (Gröning et al., 2012). The sample bottle is inside a plastic pipe and thus protected from direct sunlight. The tube that connects the sample bottle to the funnel outlet has a small diameter and extends to the bottom of the sample bottle to limit air exchange. Since the collected rainfall at Q4 is not affected by interception, the samples did not undergo canopy-induced changes in the isotopic ratio that can influence the results of hydrologic models (Stockinger et al., 2015). Additionally, a Palmex totalisator station was installed at K1 to consider elevation effects on isotope ratios and sampled approximately bi-weekly until September 2020. Since September 2020, the totalisator has been emptied daily during work days (Monday to Friday) by staff of the BOKU education centre.

Both $\delta^{18} \mathrm{O}$ and $\delta^{2} \mathrm{H}$ are analysed using laser spectroscopy (Picarro L2140-i, Picarro Inc., Santa Clara, CA, USA) in the isotope laboratory at BOKU. A calibration with laboratory reference material calibrated against the Vienna Standard Mean Ocean Water and Standard Light Antarctic Precipitation scale was used. All values are given in delta notation, and the precision of the instrument $(1 \sigma)$ was better than $0.1 \%$ and $0.5 \%$ for $\delta^{18} \mathrm{O}$ and $\delta^{2} \mathrm{H}$.

\section{Data}

All time series data are recorded, stored and routinely visualised using addVANTAGE Pro. For comprehensive analysis, data are regularly exported into the frequently used and 


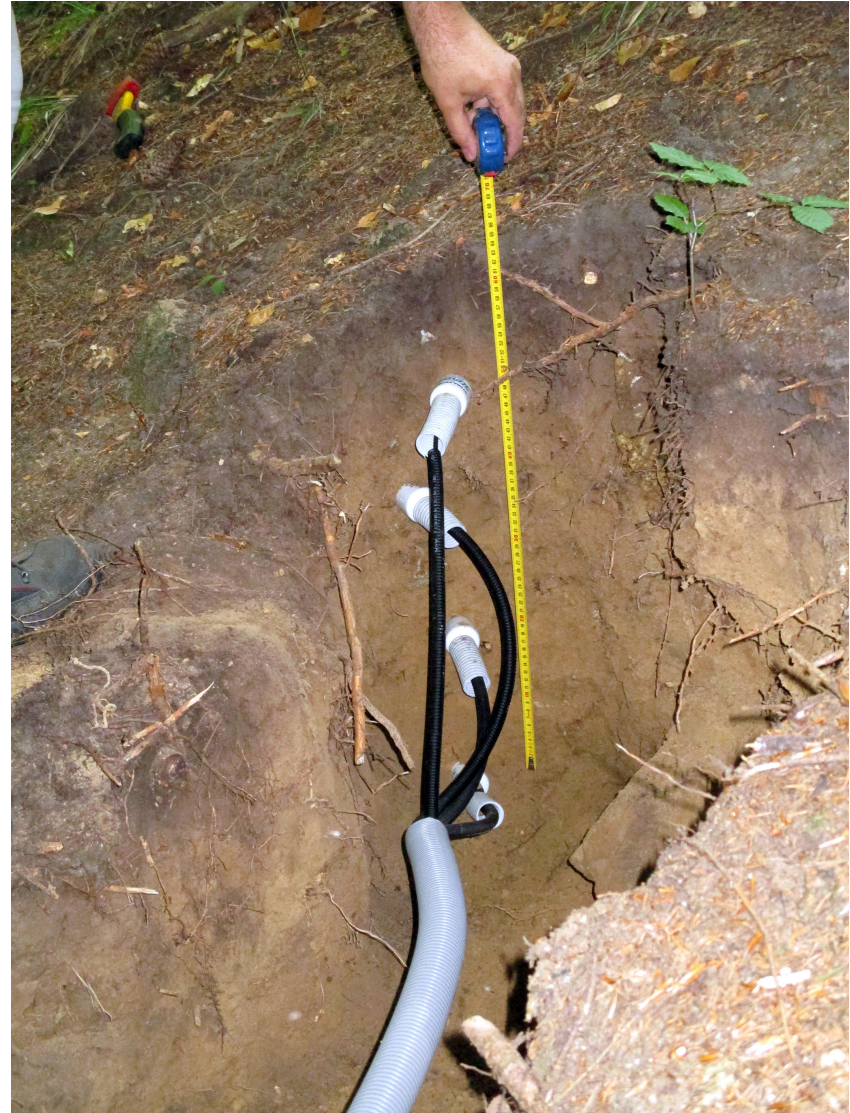

Figure 5. HydraProbe sensors installed at site Q2S0.

freely available time series management system HEC DSS and the management software HEC DSSVue (Hydrologic Engineering Center, 2010). HEC DSSVue has powerful visualisation features and provides a convenient graphical editor for the time series. During editing, obvious artefacts such as spikes generated during maintenance, occasional obstructions of flumes during storms and similar disturbances are removed from the raw data. The data cleaning is specific to the variables and is therefore discussed in detail in the respective sections below. For even more flexible and automated processing, as well as for publication, the HEC DSS database was converted into a simple SQLite database (Hipp et al., 2019), which provides efficient and simple access from different software tools, including Python and R (Müller et al., 2018).

As the implementation of the instruments started in spring 2015, the earliest time series are from sites Q1 and Q2 and start in May 2015. Until September 2015, rain gauges K1 and K2, soil water profiles Q1S0 and Q2S0, and stream gauge Q3 were also added and are delivering data. Soil water profiles Q2S1 and Q2S2 were added in April 2016 and rain gauge K3 and stream gauge Q4 in summer 2018. For the majority of the data, more than 4 years of records are currently available (spring 2021). Out of the 5 years of records available at the time of publication, only the years 2018 and 2019 are presented in the graphs below to maintain readability.

\subsection{Discharge data}

Raw discharge data at the H-flume gauges Q1, Q2 and Q4 needed careful inspection and editing. First, spikes in the hydrographs (one or two consecutive values significantly exceeding the value before and after the spike) were attributed to random events such as a leave under the ultrasonic depth sensor and were automatically replaced by linear interpolation. Next, visually detected implausible discharges were replaced by linear interpolation when reliably possible or were deleted otherwise. As an example, occasionally during very low flow (water level less than $2 \mathrm{~cm}$ in the flume), single leaves can temporarily (a few hours) get stuck at the narrow outlet of the flume and cause the water level to rise a few millimetres. Such events are clearly visible as plateau-shaped parts of the hydrograph and can be safely replaced by linear interpolation. At these gauges, the measurements have never been disturbed by freezing.

At the weir Q3, two issues required editing. (1) During very low flow, leaves and grass can occasionally get stuck at the weir crest, causing the water level to rise. These events can be detected in the images transmitted daily by a surveillance camera and visually in the hydrograph. Such artefacts are replaced by linear interpolation. (2) During longer frost periods, the stilling basin may be covered by ice, and therefore the discharge is no longer described by the weir formula. These situations can be detected by visual inspection of the hydrograph and comparison with the temperature. These parts of the records have been deleted.

Discharge is characterised by its wide range of values (Table 3). At Q3 (watershed outlet with 222 ha), low flows in summer and autumn are frequently less than $3 \mathrm{Ls}^{-1}$, while peak flows of more than $500 \mathrm{~L} \mathrm{~s}^{-1}$ have occurred twice since 2015. Specific discharge does not vary significantly between the four watersheds and typically ranges from 1 to $2 \mathrm{~L} \mathrm{~s}^{-1} \mathrm{~km}^{-2}$ during low to medium flows and up to $30 \mathrm{~L} \mathrm{~s}^{-1} \mathrm{~km}^{-2}$ during peak flows (calculated from daily means).

In the hydrographs for the period 2018 to 2019 (Fig. 6) it can be seen that the base flow is greater in spring and early summer than in autumn and winter and that sharp runoff peaks occur after rainfall events. The zoomed-in hydrographs for July/August 2018 (Fig. 7) illustrate characteristic diurnal fluctuations of discharge during no-rain periods in the vegetation period (see section "Applications" for more details).

\subsection{Precipitation data}

For quality control, rainfall data recorded by tipping bucket devices (Q1 to Q4) are compared to records of the weighing rain gauges and to corresponding hydrographs. They are deleted if the funnel appears to have been (partially) blocked. 
Table 3. Statistics of discharge records and of missing data.

\begin{tabular}{llrrrr}
\hline Site & Time period & $\begin{array}{r}\text { Min discharge } \\
\left(\mathrm{L} \mathrm{s}^{-1}\right)\end{array}$ & $\begin{array}{r}\text { Max discharge } \\
\left(\mathrm{L} \mathrm{s}^{-1}\right)\end{array}$ & $\begin{array}{r}\text { Mean discharge } \\
\left(\mathrm{L} \mathrm{s}^{-1}\right)\end{array}$ & $\begin{array}{r}\text { Percent } \\
\text { missing }\end{array}$ \\
\hline Q1 & 1 Jun 2015-31 Dec 2019 & 0.05 & 8.11 & 0.27 & 3.3 \\
Q2 & 1 Jun 2015-31 Dec 2019 & 0.24 & 12.64 & 0.81 & 0.9 \\
Q3 & 1 Sep 2015-31 Dec 2019 & 1.75 & 582.34 & 7.55 & 6.8 \\
Q4 & 1 Jul 2018-31 Dec 2019 & 1.35 & 309.68 & 4.23 & 1.1 \\
\hline
\end{tabular}
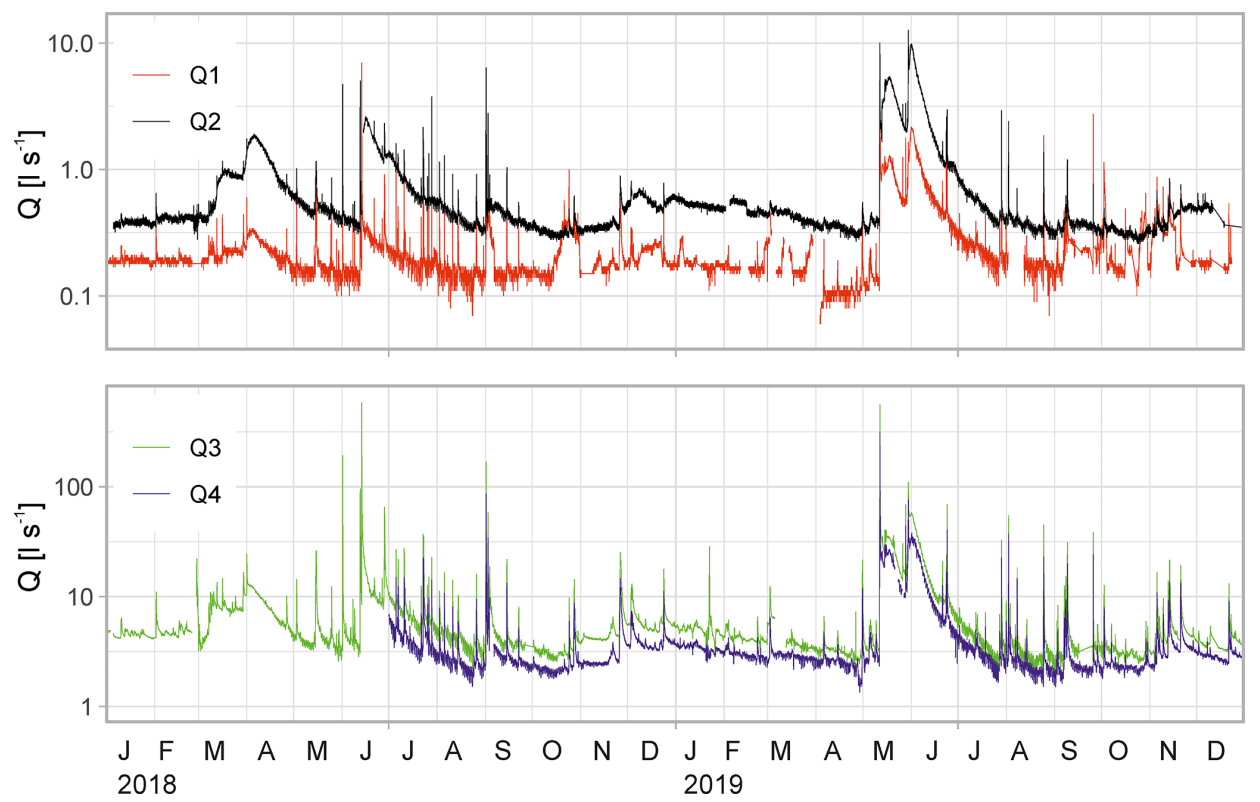

Figure 6. Discharge hydrographs at gauges Q1 to Q4 for the years 2018-2019 ( $Q$ in log scale).

Also, records for the winter season from November to February are excluded due to tipping bucket issues with freezing. Anomalies observed during field maintenance visits (one to two per month) are also considered. The three weighing rain gauges have provided gap-free records since the time of installation up to now, with a resolution of $0.1 \mathrm{~mm}$. For most rainfall events between March and October, consistent and plausible data were acquired by up to seven rain gauges in total, providing a high-resolution rainfall pattern for a small area of $222 \mathrm{ha}$ and being spread over different altitudes from 385 to 655 m a.s.l (Table 4, Fig. 8).

In this densely forested watershed, it was not possible to place all rain gauges at sites without interception or rainshading. However, the rainfall depths at the seven sites are very similar for events that cover the entire catchment. Gauge Q1 is affected by interception, which amounts to typically less than $2 \mathrm{~mm}$ per event (compared to weighing rain gauges $\mathrm{K} 1$ and $\mathrm{K} 2$ ), but monthly precipitation at $\mathrm{Q} 1$ is on average only $75 \%$ of the mean of K1 and K2. At Q2, monthly precipitation is on average $87 \%$ of the mean of $\mathrm{K} 1$ and $\mathrm{K} 2$. (K1 is close to the highest elevation of the watershed, $\mathrm{K} 2$ at the lowest; see Fig. 1 and Table 1.) Therefore, the data from all rain gauges are useful for analysing storm events as interception reduces rainfall depths by only a small percentage. For water balance investigations of periods longer than a week, however, only the gauges not affected by interception should be used.

\subsection{Soil water data}

With 14 HydraProbe sensors installed, and each measuring six variables, 84 soil-water-related time series at $10 \mathrm{~min}$ resolution are recorded, resulting in a large volume of data. In the data repository, only soil water content (SWC) and soil temperature are provided. Apart from an initial power supply problem at Q2S2, these sensors worked without any problem or data loss and required no maintenance. Figure 9 illustrates daily SWC in four depths at profile Q2S0, together with daily rainfall data. It is important to mention that the installation of the sensors requires digging a trench, which causes considerable local disturbance of the soil. Despite careful refilling, local infiltration paths could be influenced, and data do not necessarily reflect natural conditions for some time after installation. During the first few months after installation, for example, deeper probes reacted faster to rainfall than those 

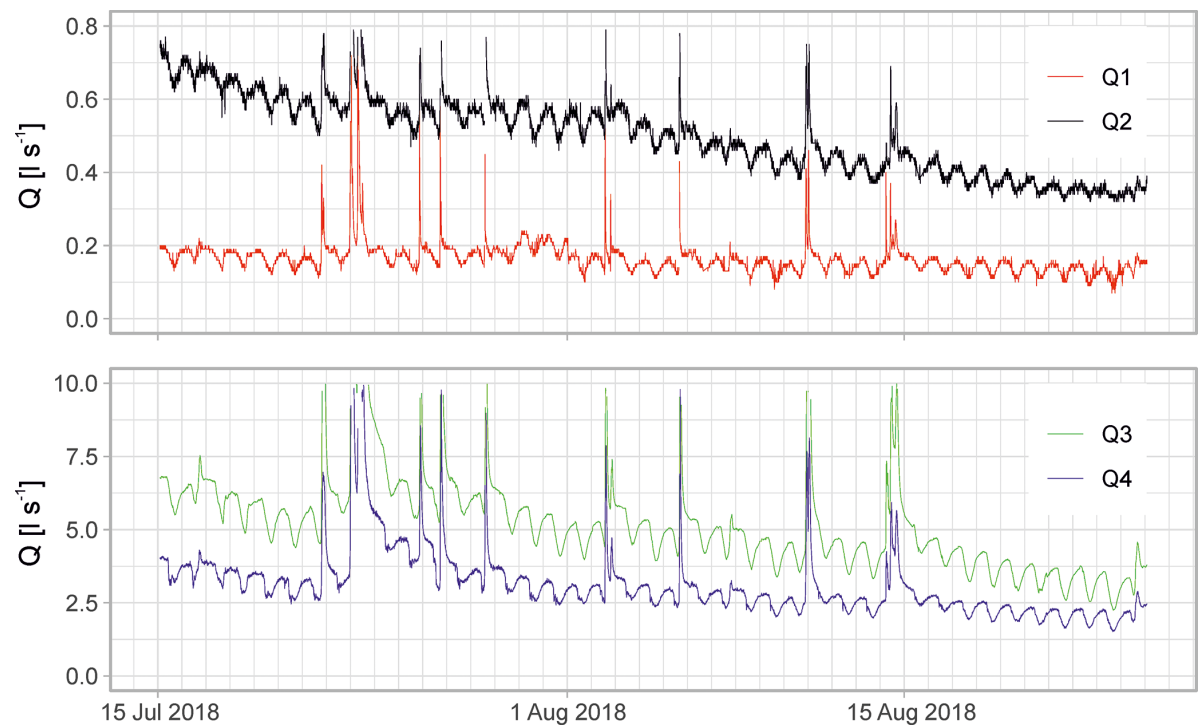

Figure 7. Diurnal fluctuations of flow for July/August 2018 (peak flows are cut off: Q1 and Q2 at 0.8 L s ${ }^{-1}$; Q3 and Q4 at 10 L s ${ }^{-1}$ ).

Table 4. Statistics of precipitation data (statistics are calculated only if there are no missing values in the interval). NA - not available

\begin{tabular}{|c|c|c|c|c|c|c|c|}
\hline \multirow[t]{2}{*}{ Site } & \multirow[t]{2}{*}{$\begin{array}{l}\text { Time } \\
\text { period }\end{array}$} & \multirow[t]{2}{*}{$\begin{array}{l}\text { Percent } \\
\text { missing }\end{array}$} & \multirow[t]{2}{*}{$\begin{array}{l}\text { Max daily } \\
\text { precip. (mm) }\end{array}$} & \multicolumn{4}{|c|}{$\begin{array}{l}\text { Annual precipitation } \\
(\mathrm{mm})\end{array}$} \\
\hline & & & & 2016 & 2017 & 2018 & 2019 \\
\hline K1 & 26 Aug 2015-31 Dec 2019 & 0 & 69.2 & 975 & 676 & 877 & 759 \\
\hline K2 & 26 Aug 2015-31 Dec 2019 & 0 & 60.8 & 949 & 682 & 906 & 739 \\
\hline K3 & 1 Aug 2018-31 Dec 2019 & 0 & 84.1 & NA & NA & NA & 737 \\
\hline Q1 & 1 Jun 2015-31 Dec 2019 & 26 & 56.6 & NA & NA & NA & NA \\
\hline Q2 & 1 Jun 2015-31 Dec 2019 & 29 & 63.0 & NA & NA & NA & NA \\
\hline Q3 & 1 Sep 2015-31 Dec 2019 & 31 & 48.6 & NA & NA & NA & NA \\
\hline Q4 & 1 Jul 2018-31 Dec 2019 & 23 & 27.0 & NA & NA & NA & NA \\
\hline
\end{tabular}

close to the surface (Fig. 10). This can be attributed to artificial flow paths along the walls of the trench and the cables, or to effects arising from interrupted and destroyed natural macropores like wormholes. However, direct effects due to installation practically disappeared after the first season.

\subsection{Electrical conductivity and temperature of runoff}

At discharge sites Q1, Q2 and Q4, water temperature and electrical conductivity are measured. Due to the risk of damage by frost, the sensors are removed during the frost period from December to March at sites Q1 and Q2. Besides frost, conductivity records at sites Q1 and Q2 are additionally negatively influenced by the sensor problems described in Sect. 3.2. Regular conductivity measurements with a portable device showed that the conductivity of base flow is stable at sites Q1 and Q2 (typically approx. $120 \mu \mathrm{S} \mathrm{cm}^{-1}$ ) so that the recorded conductivity series are still informative for the separation of base flow and direct runoff events despite conductivity offsets in the records.

\subsection{Isotopic data}

At discharge site Q4, river and precipitation samples have been collected since June and October 2019, respectively (Fig. 11). The precipitation data are collected as bi-weekly bulk samples and are compared to the daily river water grab samples. The comparison shows the response of the discharge to the precipitation input tracer signal (Fig. 11). Furthermore, the precipitation and river water isotopes vary seasonally, with larger values in summer and lower values in winter months. This seasonality originated from contributions of precipitation to discharge, and isotope ratios in precipitation seasonally vary due to changes in temperature, sources of vapour for cloud formation and different rain-out histories (Feng et al., 2009). Apart from this, there are some preliminary indications of different flow paths, such as base flow (relatively stable $\delta^{18} \mathrm{O}$ isotope values around $-10 \%$ ), interflow (moderate increases or decreases in isotopes, for example, at the beginning of August 2019), and faster flow (sharp peaks), suggesting dynamic runoff processes and tran- 

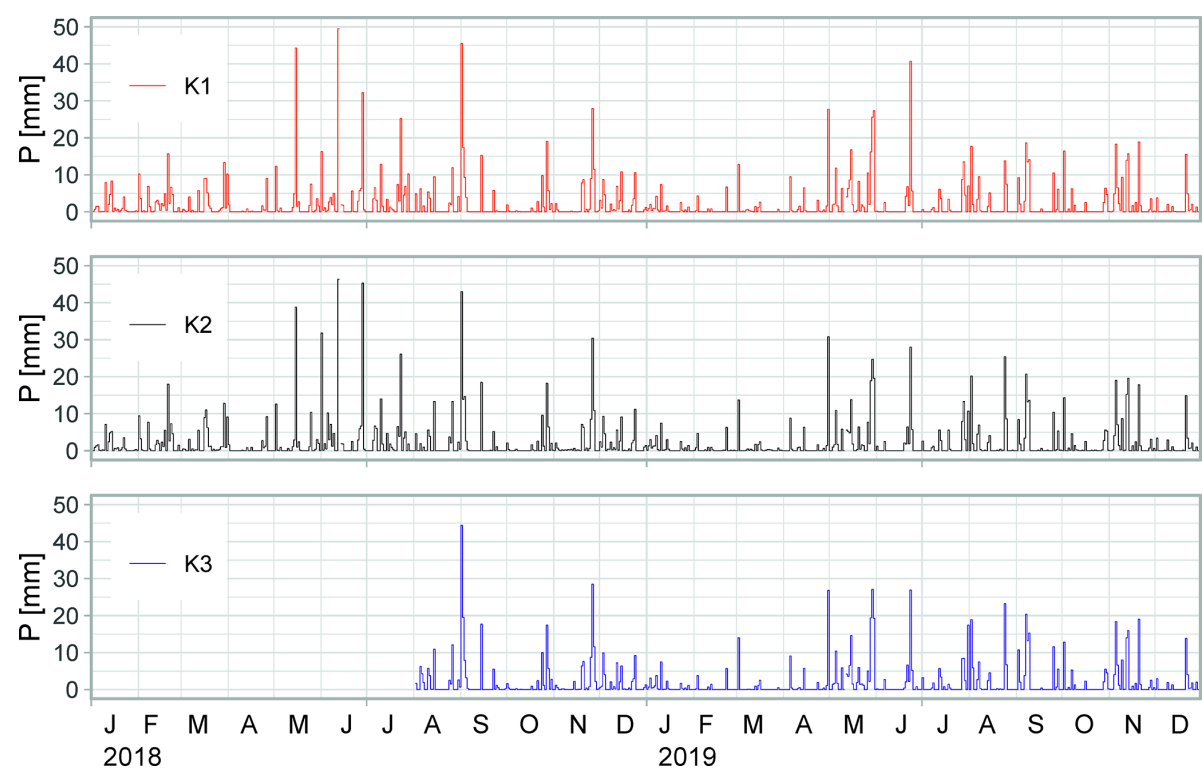

Figure 8. Daily rainfall at the weighing rain gauges for 2018 to 2019.
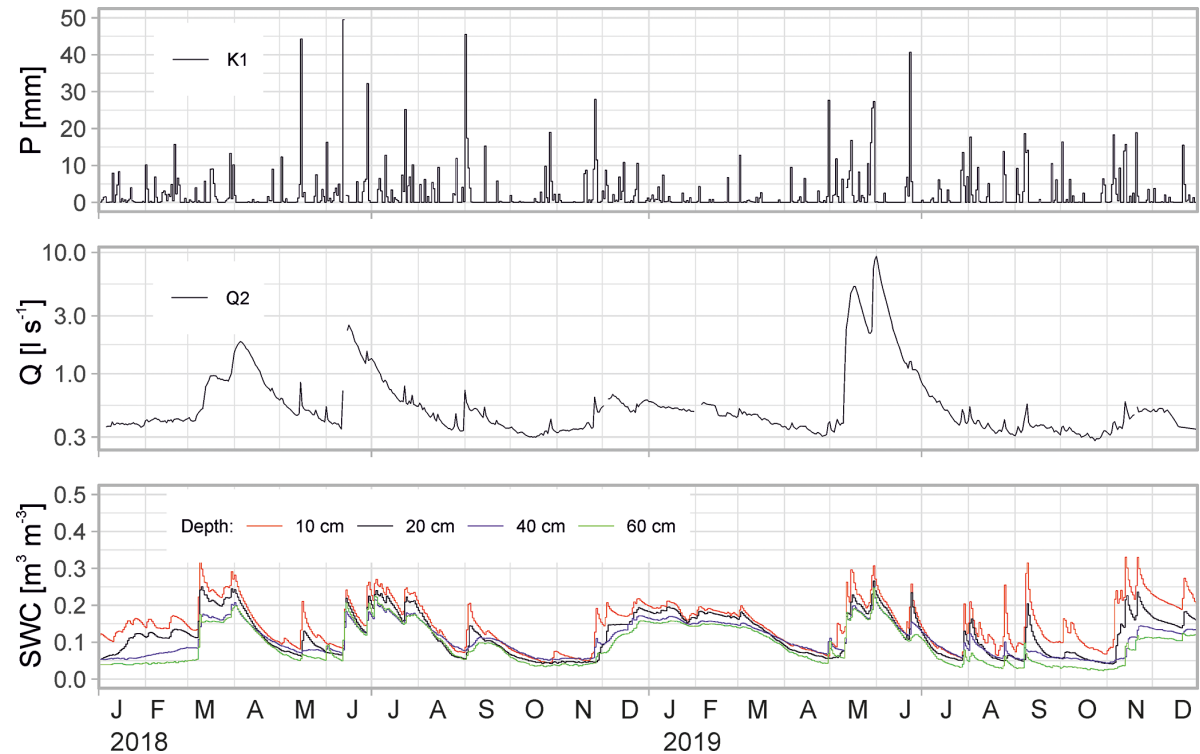

Figure 9. Daily soil water content and corresponding daily rainfall and log-discharge at site Q2S0 for 2018 to 2019.

sit times in the Rosalia watershed, which will be analysed in the future.

\subsection{Spatial data}

Data interpretation is complemented by a comprehensive amount of spatial data characterising the site. DEMs at various resolutions are available, including a $10 \times 10 \mathrm{~m}$ DEM (data source: Land Niederösterreich - http://data.noe.gv. at, last access: 29 June 2021) and a lidar-based DEM at $0.5 \times 0.5 \mathrm{~m}$ (Immitzer, 2009), accessible at https://zenodo. org/record/4601057 (last access: 29 June 2021). From these
DEMs, watershed divides and the drainage network were derived in GIS. Additionally, a ground survey was performed for the main creeks in 2018. These data are included in the repository in shapefile format.

\section{Applications}

The presented data are suitable for studying processes of water flow and transport in small, forested watersheds. They have been used in academic teaching and research. The site is regularly used for advanced field courses in the water management and environmental engineering curriculum. During 

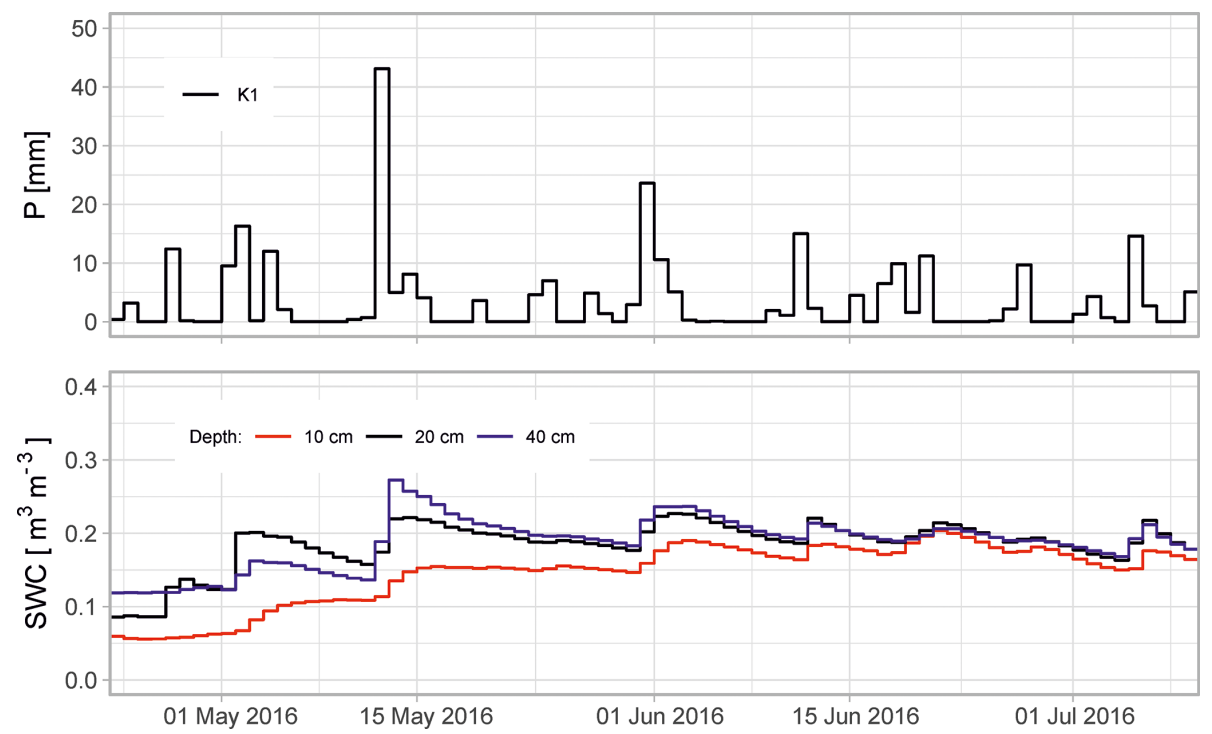

Figure 10. Detail of daily soil water content at site Q2S1: deeper sensors reacted faster to rainfall on 12 May 2016.

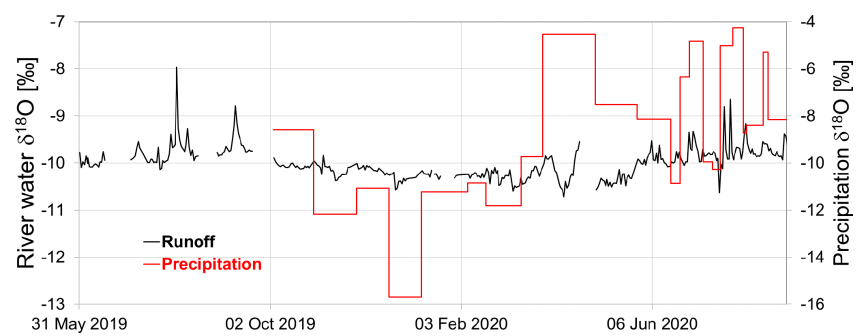

Figure 11. Precipitation and river water $\delta^{18} \mathrm{O}$ isotopes at site $\mathrm{Q} 4$.

these courses, students not only learn about the setup and operation of a hydrological monitoring network, but they also contribute to the improvement of knowledge about the watershed by collecting and analysing soil samples or performing validation measurements of the instruments.

The dataset provided the majority of the database for two master's theses and a dissertation. Irsigler (2017) applied discharge and electrical conductivity data in a simple two-endmember mixing model for the separation of base flow and direct runoff, using an approach described by Lott and Stewart (2016). Stecher (2021) investigated a phenomenon that is observed in no-rain periods during the vegetation period: daily fluctuations of discharge, with peaks at 08:00 CET up to $40 \%$ higher than the minimum at 17:00 CET, occur consistently at all four gauging sites. It was hypothesised that this is an effect of forest transpiration since these diurnal fluctuations are not observed from late autumn to early spring. By modelling a slope transect at site Q2 with HYDRUS 2D (Simunek et al., 1999), the diurnal fluctuations of discharge are demonstrated to be caused by the vegetation in the riparian zone within only a few metres of the creek. Besides the discharge and rainfall records at site $\mathrm{Q} 2$, the model also used soil moisture data at sites Q2S0, Q2S1 and Q2S2.

Wesemann (2021) investigated the influence of forest roads and skid trails on runoff during heavy rainfall events in the Rosalia catchment. Based on the $0.5 \times 0.5 \mathrm{~m}$ lidar DEM (Immitzer, 2009), he reconstructed a historical terrain model without forest roads and buildings, which allowed the comparison of the runoff from the natural terrain surface and runoff from the current surface where flow paths are modified by the forest roads. The physically based rainfall-runoff model RoGeR (Steinbrich et al., 2016) was set up for the catchment to quantify the influence of the road network on the runoff behaviour for three flood events observed at gauge Q3 between 2017 and 2019. Rainfall data from all seven rain gauges were used to assess the effect of the spatio-temporal distribution of rainfall on runoff.

\section{Data availability}

All time series data were cleaned of the most obvious errors and artefacts and stored in an easily useable database. In addition, some auxiliary spatial datasets are made available. The data described above are available at https://doi.org/10.5281/zenodo.3997140 (Fürst et al., 2020). This repository comprises an SQLite database file with all the high-resolution time series data, an MS Excel sheet with the isotopic data and the spatial datasets. Usage of the data is described by a comprehensive HTML file (generated by an $\mathrm{R}$ Markdown document also included), which includes previews and a full technical description of the data, including $R$ code chunks to read and visualise them. The data repository will be updated annually. 


\section{Summary}

The data presented in this article represent an effort to measure components of the energy and water cycle in a forested catchment in the eastern Austrian Alps. The period of record for precipitation, discharge, air and water temperature, relative humidity, electrical conductivity, and soil water content started in 2015 . Water quality monitoring and sampling for precipitation and river water $\delta^{18} \mathrm{O}$ isotopes were added in 2018 and 2019. Measurements use consistent methods to ensure comparability within the research catchment. The data have proven fit for the purpose of supporting hydrological and hydro-meteorological process research. Making the data available to the research and applied hydrology communities has two main objectives. First, it intends to inform decision-makers in the Rosalia forest. The record is an important source of baseline data that can be used to assess the effect of disturbances such as clear-cuts and changing forestry on hydrological processes. Second, these data are provided to allow others to also investigate hydrological processes, medium-term patterns and potential changes in this type of watershed.

Author contributions. JF was involved in field work to collect the data discussed here, including selection and installation of the instruments, processing, quality assurance, and quality control. HPN and KS handled strategic decisions and funding. JG provided advice on site selection and provided some spatial data. RN handled the selection and installation of soil sensors. MS and CS set up the isotope measurement network and maintain it. All the authors contributed to writing the manuscript.

Competing interests. The authors declare that they have no conflict of interest. Names of products and companies are only mentioned for better understanding and traceability; none of the authors are associated with any of the mentioned companies.

Disclaimer. Publisher's note: Copernicus Publications remains neutral with regard to jurisdictional claims in published maps and institutional affiliations.

Acknowledgements. Over the years, several people have contributed to the implementation of the Rosalia test site, the operation of the instruments and data collection and deserve recognition. These include Wisam Almohamed, Matthias Bernhardt, Laurin Bonell, Reinhard Burgholzer, Roman Eque, Heinz Fassl, Martin Hackl, Mathew Herrnegger, Freddy Kratzert, Thomas Lehner, Martin Lichtblau, Johann Karner, Philipp Proksch, Andreas Schwen, Wolfgang Sokol, Gabriel Stecher and Johannes Wesemann.

Review statement. This paper was edited by Lukas Gudmundsson and reviewed by two anonymous referees.
References

Anderson, S. P., Bales, R. C., and Duffy, C. J.: Critical Zone Observatories: Building a network to advance interdisciplinary study of Earth surface processes, Mineral. Mag., 72, 7-10, https://doi.org/10.1180/minmag.2008.072.1.7, 2018.

Bernhardt, M., Schulz, K., and Pomeroy, J. W.: The International Network for Alpine Research Catchment Hydrology: A new GEWEX crosscutting Project, Hydrol. Wasserbewirts., 59, 190191, 2015.

Blöschl, G., Blaschke, A. P., Broer, M., Bucher, C., Carr, G., Chen, X., Eder, A., Exner-Kittridge, M., Farnleitner, A., Flores-Orozco, A., Haas, P., Hogan, P., Kazemi Amiri, A., Oismüller, M., Parajka, J., Silasari, R., Stadler, P., Strauss, P., Vreugdenhil, M., Wagner, W., and Zessner, M.: The Hydrological Open Air Laboratory (HOAL) in Petzenkirchen: a hypothesis-driven observatory, Hydrol. Earth Syst. Sci., 20, 227-255, https://doi.org/10.5194/hess20-227-2016, 2016.

Blöschl, G., Bierkens, M. F. P., Chambel, A., Cudennec, C., Destouni, G., Fiori, A., Kirchner, J. W., McDonnell, J. J., Savenije, H. H. G., Sivapalan, M., Stumpp, C., Toth, E., Volpi, E., Carr, G., Lupton, C., Salinas, J., Széles, B., Viglione, A., Aksoy, H., Allen, S. T., Amin, A., Andréassian, V., Arheimer, B., Aryal, S. K., Baker, V., Bardsley, E., Barendrecht, M. H., Bartosova, A., Batelaan, O., Berghuijs, W. R., Beven, K., Blume, T., Bogaard, T., Borges de Amorim, P., Böttcher, M. E., Boulet, G., Breinl, K., Brilly, M., Brocca, L., Buytaert, W., Castellarin, A., Castelletti, A., Chen, X., Chen, Y., Chen, Y., Chifflard, P., Claps, P., Clark, M. P., Collins, A. L., Croke, B., Dathe, A., David, P. C., de Barros, F. P. J., de Rooij, G., Di Baldassarre, G., Driscoll, J. M., Duethmann, D., Dwivedi, R., Eris, E., Farmer, W. H., Feiccabrino, J., Ferguson, G., Ferrari, E., Ferraris, S., Fersch, B., Finger, D., Foglia, L., Fowler, K., Gartsman, B., Gascoin, S., Gaume, E., Gelfan, A., Geris, J., Gharari, S., Gleeson, T., Glendell, M., Gonzalez Bevacqua, A., González-Dugo, M. P., Grimaldi, S., Gupta, A. B., Guse, B., Han, D., Hannah, D., Harpold, A., Haun, S., Heal, K., Helfricht, K., Herrnegger, M., Hipsey, M., Hlaváčiková, H., Hohmann, C., Holko, L., Hopkinson, C., Hrachowitz, M., Illangasekare, T. H., Inam, A., Innocente, C., Istanbulluoglu, E., Jarihani, B., Kalantari, Z., Kalvans, A., Khanal, S., Khatami, S., Kiesel, J., Kirkby, M., Knoben, W., Kochanek, K., Kohnová, S., Kolechkina, A., Krause, S., Kreamer, D., Kreibich, H., Kunstmann, H., Lange, H., Liberato, M. L. R., Lindquist, E., Link, T., Liu, J., Loucks, D. P., Luce, C., Mahé, G., Makarieva, O., Malard, J., Mashtayeva, S., Maskey, S., Mas-Pla, J., Mavrova-Guirguinova, M., Mazzoleni, M., Mernild, S., Misstear, B. D., Montanari, A., Müller-Thomy, H., Nabizadeh, A., Nardi, F., Neale, C., Nesterova, N., Nurtaev, B., Odongo, V. O., Panda, S., Pande, S., Pang, Z., Papacharalampous, G., Perrin, C., Pfister, L., Pimentel, R., Polo, M. J., Post, D., Prieto Sierra, C., Ramos, M.-H., Renner, M., Reynolds, J. E., Ridolfi, E., Rigon, R., Riva, M., Robertson, D. E., Rosso, R., Roy, T., Sá, J. H. M., Salvadori, G., Sandells, M., Schaefli, B., Schumann, A., Scolobig, A., Seibert, J., Servat, E., Shafiei, M., Sharma, A., Sidibe, M., Sidle, R. C., Skaugen, T., Smith, H., Spiessl, S. M., Stein, L., Steinsland, I., Strasser, U., Su, B., Szolgay, J., Tarboton, D., Tauro, F., Thirel, G., Tian, F., Tong, R., Tussupova, K., Tyralis, H., Uijlenhoet, R., van Beek, R., van der Ent, R. J., van der Ploeg, M., Van Loon, A. F., van Meerveld, I., van 
Nooijen, R., van Oel, P. R., Vidal, J.-P., von Freyberg, J., Vorogushyn, S., Wachniew, P., Wade, A. J., Ward, P., Westerberg, I. K., White, C., Wood, E. F., Woods, R., Xu, Z., Yilmaz, K. K., and Zhang, Y.: Twenty-three unsolved problems in hydrology (UPH) - a community perspective, Hydrolog. Sci. J., 64, 1141-1158, https://doi.org/10.1080/02626667.2019.1620507, 2019.

Bogena, H. R., White, T., Bour, O., Li, X., and Jensen, K. H.: Toward Better Understanding of Terrestrial Processes through Long-Term Hydrological Observatories, Vadose Zone J., 17, 110, https://doi.org/10.2136/vzj2018.10.0194, 2018.

Cosby, J. and Emmett, B.: Plynlimon Experimental Catchments: available at: https://www.ceh.ac.uk/our-science/projects/ plynlimon-experimental-catchments, last access: 28 May 2020.

ESFRI: Roadmap \& Strategy Report on Research Infrastructures: available at: http://roadmap2018.esfri.eu/media/1066/ esfri-roadmap-2018.pdf, last access: 28 May 2020.

Feng, X., Faiia, A. M., and Posmentier, E. S.: Seasonality of isotopes in precipitation: A global perspective, J. Geophys. Res.Atmos., 114, D08116, https://doi.org/10.1029/2008JD011279, 2009.

Fürst, J., Nachtnebel, H. P., Gasch, J., Nolz, R., Stockinger, M. P., Stumpp, C., and Schulz, K.: Rosalia: an experimental research site to study hydrological processes in a forest catchment - data repository, Zenodo [data set], https://doi.org/10.5281/zenodo.3997141, 2020.

Gröning, M., Lutz, H. O., Roller-Lutz, Z., Kralik, M., Gourcy, L., and Pöltenstein, L.: A simple rain collector preventing water re-evaporation dedicated for $\delta 18 \mathrm{O}$ and $\delta 2 \mathrm{H}$ analysis of cumulative precipitation samples, J. Hydrol., 448-449, 195-200, https://doi.org/10.1016/j.jhydrol.2012.04.041, 2012.

Haberl, H., Winiwarter, V., Andersson, K., Ayres, R. U., Boone, C., Castillo, A., Cunfer, G., Fischer-Kowalski, M., Freudenburg, W. R., Furman, E., Kaufmann, R., Krausmann, F., Langthaler, E., Lotze-Campen, H., Mirtl, M., Redman, C. L., Reenberg, A., Wardell, A., Warr, B., and Zechmeister, H.: From LTER to LTSER: Conceptualizing the Socioeconomic Dimension of Long-term Socioecological Research, Ecol. Soc., 11, 13, https://doi.org/10.5751/ES-01786-110213, 2006.

Hipp, D. R., Kennedy, D., and Mistachkin, J.: SQLite SQLite Development Team, available at: https://www.sqlite.org/download. html (last access: 29 June 2021), 2019.

Holzmann, H.: Status and perspectives of hydrological research in small basins in Europe, Geographical Research Letters, 44, 601614, https://doi.org/10.18172/cig.3406, 2018.

Hydrologic Engineering Center: HEC DSSVue Version 2.0, US Army Corps of Engineers, Institute for Water Resources, Davis, CA, 2010.

Immitzer, M.: Auswertung von Airborne-Laser-Scanning-Daten für die Ableitung des Holzvorrates im Lehrforst der Universität für Bodenkultur, MSc thesis, University of Natural Resources and Life Sciences Vienna, Vienna, 163 pp., 2009.

Irsigler, S. Z.: Nutzung von Leitfähigkeits- und Temperaturdaten zur verbesserten Beschreibung der Abflussprozesse in kleinen bewaldeten Einzugsgebieten, MSc thesis, Wasser - Atmosphäre - Umwelt, Universität für Bodenkultur Wien, Wien, 128 pp., 2017.

Kampe, T., Johnson, B., Kuester, M., and Keller, M.: NEON: the first continental-scale ecological observatory with airborne remote sensing of vegetation canopy biochem- istry and structure, J. Appl. Remote Sens., 4, 043510 , https://doi.org/10.1117/1.3361375, 2010.

Laudon, H., Taberman, I., Ågren, A., Futter, M., OttossonLöfvenius, M., and Bishop, K.: The Krycklan Catchment Study - A flagship infrastructure for hydrology, biogeochemistry, and climate research in the boreal landscape, Water Resour. Res., 49, 7154-7158, https://doi.org/10.1002/wrcr.20520, 2013.

Leitner, S., Minixhofer, P., Inselsbacher, E., Keiblinger, K. M., Zimmermann, M., and Zechmeister-Boltenstern, S.: Short-term soil mineral and organic nitrogen fluxes during moderate and severe drying-rewetting events, Appl. Soil Ecol., 114, 28-33, https://doi.org/10.1016/j.apsoil.2017.02.014, 2017.

Lott, D. A. and Stewart, M. T.: Base flow separation: A comparison of analytical and mass balance methods, J. Hydrol., 535, 525533, https://doi.org/10.1016/j.jhydrol.2016.01.063, 2016.

LTER Network Office: LTER History, available at: https://lternet. edu/network-organization/lter-a-history/, last access: 28 May 2020.

Morgenschweis, G.: Hydrometrie - Theorie und Praxis der Durchflussmessung in offenen Gerinnen, Springer-Verlag, Berlin Heidelberg, 582 pp., 2010.

Müller, K., Wickham, H., James, D. A., and Falcon, S.: RSQLite: "SQLite" Interface for R. R package version 2.1.1, available at: https://CRAN.R-project.org/package=RSQLite (last access: 29 June 2021), 2018.

Neal, C., Reynolds, B., Norris, D., Kirchner, J. W., Neal, M., Rowland, P., Wickham, H., Harman, S., Armstrong, L., Sleep, D., Lawlor, A., Woods, C., Williams, B., Fry, M., Newton, G., and Wright, D.: Three decades of water quality measurements from the Upper Severn experimental catchments at Plynlimon, Wales: an openly accessible data resource for research, modelling, environmental management and education, Hydrol. Process., 25, 3818-3830, https://doi.org/10.1002/hyp.8191, 2011.

Netherer, S., Matthews, B., Katzensteiner, K., Blackwell, E., Henschke, P., Hietz, P., Pennerstorfer, J., Rosner, S., Kikuta, S., Schume, H., and Schopf, A.: Do water-limiting conditions predispose Norway spruce to bark beetle attack?, New Phytol., 205, 1128-1141, https://doi.org/10.1111/nph.13166, 2015.

Porporato, A. and Rodriguez-Iturbe, I.: Ecohydrologya challenging multidisciplinary research perspective/Ecohydrologie: une perspective stimulante de recherche multidisciplinaire, Hydrolog. Sci. J., 47, 811-821, https://doi.org/10.1080/02626660209492985, 2002.

Schumann, S., Schmalz, B., Meesenburg, H., and Schröder, U.: Status and Perspectives of Hydrology in Small Basins - Results and recommendations of the International Workshop in GoslarHahnenklee, Germany, 2009 and Inventory of Small Hydrological Research Basins, German National Committee for the International Hydrological Programme (IHP) of UNESCO and the Hydrology and Water Resources Programme (HWRP) of WMO KoblenzIHP/HWRP-Berichte, Heft 10, 71 pp., 2010.

Schwen, A., Zimmermann, M., Leitner, S., and Woche, S. K.: Soil Water Repellency and its Impact on Hydraulic Characteristics in a Beech Forest under Simulated Climate Change, Vadose Zone J., 14, vzj2015.2006.0089, https://doi.org/10.2136/vzj2015.06.0089, 2015.

Seyfried, M., Lohse, K., Marks, D., Flerchinger, G., Pierson, F., and Holbrook, W. S.: Reynolds Creek Experimental Watershed 
and Critical Zone Observatory, Vadose Zone J., 17, 180129, https://doi.org/10.2136/vzj2018.07.0129, 2018.

Seyfried, M. S., Grant, L. E., Du, E., and Humes, K.: Dielectric loss and calibration of the Hydra Probe Soil Water Sensor, Vadose Zone J., 4, 1070-1079, 2005.

Simunek, J., Sejna, M., and van Genuchten, M. T.: The Hydrus-2D software package for simulating two-dimensional movement of water, heat, and multiple solutes in variably saturated media, IGWMC - TPS - 53, International Ground Water Modeling Center, Colorado School of Mines, Golden, Colorado, 251 pp., 1999.

Stecher, G.: Analyses of diurnal discharge fluctuations in forested micro-watersheds (Lehrforst Rosalia), M.Sc. thesis, University of Natural Resources and Life Sciences Vienna, Vienna, 118 pp., 2021.

Steinbrich, A., Leistert, H., and Weiler, M.: Model-based quantification of runoff generation processes at high spatial and temporal resolution, Environ. Earth Sci., 75, 1423, https://doi.org/10.1007/s12665-016-6234-9, 2016.

Stevens Water Monitoring Systems: Comprehensive Stevens HydraProbe user's manual, rev. IV, Portland, 2015.

Stockinger, M., Lücke, A., McDonnell, J., Diekkrüger, B., Vereecken, H., and Bogena, H.: Interception effects on stable isotope driven streamwater transit time estimates, Geophys. Res. Lett., 42, 5299-5308, https://doi.org/10.1002/2015GL064622, 2015.
Thomson, J.: On experiments on the measurement of water by triangular notches in weir-boards, British Ass. for Advancement of Science, London, 181-185, 1859.

von Freyberg, J., Knapp, J. L. A., Rücker, A., Studer, B., and Kirchner, J. W.: Technical note: Evaluation of a low-cost evaporation protection method for portable water samplers, Hydrol. Earth Syst. Sci., 24, 5821-5834, https://doi.org/10.5194/hess-24-58212020, 2020.

Wesemann, J.: Hydrologische Modellierung des natürlichen Abflussverhaltens und dessen Veränderung durch anthropogene Einflüsse, PhD thesis, University of Natural Resources and Life Sciences Vienna, Vienna, 175 pp., 2021.

WMO: Guide to Hydrological Practices Volume I Hydrology - From Measurement to Hydrological Information, 6th Edn., Geneva, Switzerland, 2008.

Zacharias, S., Bogena, H., Samaniego, L., Mauder, M., Fuß, R., Pütz, T., Frenzel, M., Schwank, M., Baessler, C., ButterbachBahl, K., Bens, O., Borg, E., Brauer, A., Dietrich, P., Hajnsek, I., Helle, G., Kiese, R., Kunstmann, H., Klotz, S., Munch, J. C., Papen, H., Priesack, E., Schmid, H. P., Steinbrecher, R., Rosenbaum, U., Teutsch, G., and Vereecken, H.: A Network of Terrestrial Environmental Observatories in Germany, Vadose Zone J., 10, 955-973, https://doi.org/10.2136/vzj2010.0139, 2011. 